\title{
LITERASI PSIKOPEDAGOGIK: MEMBACA KARAKTER TOKOH DALAM NOVEL CINTA DI UJUNG SAJADAH KARYA ASMA NADIA SEBAGAI MATERI PEMBELAJARAN SASTRA PADA SATUAN PENDIDIKAN SEKOLAH MENENGAH ATAS
}

\author{
Sitti Nertie Astuti ${ }^{1}$, Muhsyanur ${ }^{2}$, Sri Wahyuni ${ }^{3}$ \\ ${ }^{1}$ Universitas Puangrimaggalatung \\ ${ }^{2}$ Institut Agama Islam (IAI) As’adiyah Sengkang \\ ${ }^{3}$ Universitas Khairun \\ Author Correspondence: muhsyanursyahrir85@gmail.com
}

\begin{abstract}
Abstrak
Penelitian ini bertujuan untuk mendeskripsikan karakter tokoh dalam novel Cinta di Ujung Sajadah karya Asma Nadia sebagai materi pembelajaran sastra pada satuan pendidikan Sekolah Menengah Atas (SMA). Penelitian ini merupakan penelitian kualitatif deskriptif. Sumber dan data penelitian ini ialah novel Cinta di Ujung Sajadah karya Asma Nadia. Data-data dikumpulkan dengan menggunakan teknik membaca intensif dan sistem pengodean. Selanjutnya, data-data diolah dengan tahap koleksi dan organisasi. Sementara proses analisis data menggunakan teknik interpretasi. Hasil penelitian menunjukkan bahwa: (1) nilai pendidikan karakter yang terkandung dalam novel Cinta di Ujung Sajadah mencakup nilai religius, jujur, bertanggungjawab, toleransi, rasa ingin tahu, peduli sosial, dan komunikatif; (2) novel Cinta di Ujung Sajadah dapat digunakan sebagai materi pembelajaran sastra pada satuan pendidikan Sekolah Menengah Atas (SMA).
\end{abstract}

Kata Kunci: nilai, pendidikan, karakter, pembelajaran

\begin{abstract}
This study aims to describe the characters in the novel Cinta di Ujung Sajadah by Asma Nadia as literary learning material in secondary education units (high schools). This research is a descriptive qualitative research. The sources and data of this research are the novel Cinta di Ujung Sajadah by Asma Nadia. Data is collected using intensive reading techniques and coding systems. Furthermore, data is processed at the collection and organizational stages. While the data analysis process uses interpretation techniques. The results showed that: (1) the value of character education contained in the novel Cinta di Ujung Sajadah includes religious values, honesty, responsibility, tolerance, curiosity, social care, and communicative; (2) Novels of Love in Ujung Sajadah can be used as literary learning material in high school (SMA) education units.
\end{abstract}

Keywords: values, education, character, learning

\section{PENDAHULUAN}

Karya sastra merupakan rekaan sastrawan yang bersifat imajinatif. Karya sastra dapat menggambarkan keadaan dan situasi tertentu pada suatu zaman dengan gayanya yang khas. Pengarang ingin menuangkan idenya dalam suatu karya sastra, pada hakikatnya sebuah karya sastra adalah replika kehidupan nyata. Walaupun berbentuk fiksi, misalnya cerpen, novel, dan drama, persoalan yang disodorkan oleh pengarang yang tidak terlepas dari kehidupan nyata (Widiyastuti, 2016, p. 1). 
Kegunaan yang mampu menjadikan para penikmatnya peka terhadap masalah-masalah kemanusiaan, mendorong lahirnya perilaku-perilaku yang mendatangkan manfaat bagi kehidupan. Salah satu bentuk karya sastra yang membicarakan manusia dengan segala perilaku dan kepribadiannya dalam kehidupan adalah novel.Novel juga merupakan bentuk cerita fiksi yang didalam cerita baik fiksi maupun fakta pasti mengandung nilai-nilai tertentu yang berkaitan dengan moral/karakter.

Menurut Mulyasa (Sulaiman, 2015, p. 2)pendidikan karakter adalah suatu sistem penanaman nilai-nilai karakter kepada peserta didik yang meliputi komponen kesadaran, pemahaman, kepedulian dan komitmen yang tinggi untuk melaksanakan nilai-nilai tersebut, baik terhadap Allah Yang Maha Esa, diri sendiri, lingkungan maupun bangsa secara keseluruhan sehingga menjadi manusia sesuai kodratnya. Penanaman nilai-nilai karakter dapat dilakukan dalam pembelajaran, misalnya pada pengajaran sastra.

Pengajaran sastra perlu diberikan kepada siswa sekolah lanjutan untuk mengarahkan dan membentuk pribadi siswa yang halus, manusiawi, dan berbudaya sesuai dengan tujuan pembelajaran sastra. Selanjutnya, sesuai dengan tujuan pengajaran umum Bahasa dan Sastra Indonesia yaitu siswa mampu menikmati, menghayati, memahami, dan memanfaatkan karya satra untuk mengembangkan kepribadian, memperluas wawasan kehidupan, memperhalus budi pekerti, serta meningkatkan pengetahuan dan kemampuan berbahasa (Depdiknas, 2007, p. 1).

Perlu diingat bahwa tidak semua karya sastra, khususnya novel baik untuk dibaca karena tidak semua novel mengandung nilai moral pendidikan, budaya, dan agama. Oleh karena itu, suatu keharusan bagi seorang guru Bahasa dan Sastra Indonesia untuk memilih, membaca, memahami, dan menilai terlebih dahulu karya sastra (novel) yang akan diajarkan kepada anak didiknya.

Indonesia memiliki beberapa novelis terbaik, seperti Pipit Senja, Habiburrahman El-Shirazy dan salah satunya yakni Asma Nadia.Asma Nadia adalah penulis yang produktif, dia sudah menulis lebih dari 50 buku.Berbagai penghargaan nasional dan regional dibidang kepenulisan juga telah diraihnya.Diantaranya adalah penghargaan sebagai Pengarang Terbaik Nasional penerima Adikarya Ikapi Award tahun 2000, 2001, dan 2005. Peraih penghargaan dari Majelis Sastra Asia Tenggara (Mastera) tahun 2005, Anugrah IBF Award sebagai novelis terbaik tahun 2008, Peserta Terbaik lokakarya perempuan penulis naskah drama yang diadakan FIB UI dan Dewan kesenian Jakarta (Wibowo, 2012).

Salah satu novel karya Asma Nadia yang termasuk best selleryakniyang berjudul Cinta di Ujung Sajadah, yang menceritakan seorang gadis berumur 17 tahun yang berjuang untuk menemukan ibu kandungnya. Sebuah penelitian agar mempunyai orisinalitas perlu adanya penelitian yang relevan. Penelitian yang relevan berfungsi untuk memberikan pemaparan tentang penelitian dan analisis sebelumnya yang telah dilakukan. Penelitian yang membahas mengenai nilai-nilai pendidikan karakter dalam sebuah karya sastra sebelumnya sudah pernah diteliti oleh beberapa peneliti. Pertama, Suwarni (2014) dengan judul Nilai-Nilai Pendidikan Karakter dalam Novel Moga Bunda Disayang Allah Karya TereLiye STAIN Purwokerto tahun 2014. Kedua, Sakti (2013) yang berjudul Nilai Pendidikan Karakter Novel Bumi Cinta Karya Habiburrahman El Shirazy dan Relevansinya terhadap Materi Pembelajaran Sastra di SMA.

Secara mendasar penelitian tentang novel Cinta di Ujung Sajadah karya Asma Nadia belum pernah dilakukan. Hal yang menarik dari penelitian ini adalah bagaimana melakukan eksplorasi akan kandungan nilai-nilai pendidikan karakter dalam novel Cinta di Ujung Sajadah. Novel ini memberikan inspirasi bagi para pembaca untuk menghargai seorang ibu.

\section{Pendekatan Didaktis}

Kegiatan membaca atau menikmati karya sastra dengan cara seperti menonton atau menyimak pembacaan karya sastra, hendaknya dilakukan secara sungguh-sungguh supaya memiliki daya kepekaan pikir dan perasaan untuk dapat menghayati makna dan isi karya sastra tersebut sehingga 
akan memperoleh manfaat yang besar dari kegiatan yang dilakukan. Kegiatan yang memperoleh manfaat, pengalaman, serta penilaian terhadap karya sastra inilah yang menggambarkan terjadinya kegiatan dalam mengapresiasi sastra.

Salah satu kegiatan dalam mengapresiasi karya sastra dapat dilakukan dengan menganalisis suatu hasil karya sastra.Seperti halnya dalam penelitian ini yaitu mengkaji nilai pendidikan karakter dalam novel Cinta di Ujung Sajadah karya Asma Nadia.Dalam menganalisis suatu hasil karya sastra tentu saja diperlukan adanya sebuah pendekatan untuk dapat menunjang keberhasilan dari tujuan yang hendak dicapai (Desi, 2013, p. 9).

Menurut Depdiknas (2008, p. 306) pendekatan berarti proses, pembuatan, cara mendekati (hendak berdamai, bersahabat dan sebagainya). Pendekatan sebagai suatu prinsip dasar yang digunakan seseorang ketika mengapresiasi karya sastra dapat bermacam-macam. Pendekatan yang relevan dengan penelitian ini adalah pendekatan didaktis. Menurut Umami (2012, p. 1) pendekatan didaktis adalah suatu pendekatan yang berusaha menemukan dan memahami gagasan, tanggapan maupun sikap itu dalam hal ini akan mampu terwujud dalam suatu pandangan etis, filosofis, maupun agamais sehingga akan mengandung nilai-nilai yang mampu memperkaya kehidupan rohaniah pembaca. Namun, menurut Desi (2013, p. 9) bahwa pendekatan didaktis pendekatan yang berusaha menemukan dan memahami gagasan, tanggapan evaluasi maupun sikap pengarang terhadap kehidupan.

Pendekatan didaktis ini pada dasarnya juga merupakan suatu pendekatan yang telah beranjak jauh dari pesan yang tersurat yang terdapat dalam suatu cipta sastra. Sebab itulah penerapan pendekatan didaktis dalam apresiasi serta akan menuntut daya kemampuan intelektual, kepekaan rasa maupun sikap yang mapan dari pembaca. Nilai didaktis adalah suatu penghargaan hasil karya sastra yang bersifat mendidik, dapat memberikan keteladanan bagi seluruh pembaca, para pembaca dapat mengambil hikmah yang terkandung dalam nilai-nilai yang ada dalam karya sastra.

Berdasarkan pendapat yang diuraikan diatas, dapat disimpulkan bahwa selain untuk menyelaraskan nilai-nilai pendidikan yang terkandung dalam karya sastra dengan tingkat pemahaman siswa, pendekatan didaktis juga berfungsi sebagai penyeleksi terhadap banyaknya karya sastra yang beredar di masyarakat. Oleh karena itu, dalam penerapannya apabila dikaitkan dengan pembelajaran sastra, pendekatan didaktis menjadi lebih bermakna khususnya dalam ketepatan hal pemilihan bahan yang hendak diajarkan kepada siswa Desi (2015, p. 11). Selain hal tersebut, penggunaan pendekatan didaktis berkaitan dengan penelitian terhadap nilai karakter dalam novel Cinta di Ujung Sajadah karya Asma Nadia, maka penggunaan pendekatan didaktis ini dalam penelitian tersebut telah sesuai, karena pada dasarnya adalah untuk menunjang tujuan dari penelitian tersebut yaitu untuk menemukan dan memahami nilai-nilai pendidikan yang terkandung dalam novel Cintadi Ujung Sajadah karya Asma Nadia untuk dijadikan sebagai materi pembelajaran sastra pada satuan pendidikan Sekolah Menengah Atas (SMA).

\section{Hakikat Nilai Pendidikan Karakter}

Darmodiharjo (2010, p. 233) mengatakan bahwa nilai adalah sifat atau kualitas dari sesuatu yang bermanfaat bagi kehidupan manusia, baik lahir maupun batin. Bagi manusia nilai dijadikan landasan atau motivasi dalam bersikap dan bertingkah laku, baik didasari atau tidak. Selain itu, Gazalba (Lubis, 2008, p. 17), nilai adalah sesuatu yang bersifat abstrak dan ideal, nilai buku berupa konkret, bukan fakta tidak sekadar penghayatan yang dikehendaki, yang disenangi atau yang tidak disenangi, akan tetapi nilai itu terletak antara hubungan subjek penilai dengan objek. Hal ini mengandung pengertian bahwa adanya sebuah nilai dikarenakan hubungan antara subjek penilai dengan objek yang dinilainya. Lubis (2008, p. 18) mengatakan bahwa nilai merupakan esensi yang melekat pada sesuatu yang sangat berarti dalam kehidupan manusia. Keberadaan nilai akan menjadi tampak, seiring dengan kebutuhan yang diperlukan terhadap sesuatu tersebut. Nilai dapat dikatakan sebagai sesuatu yang berguna bagi kehidupan manusia. 
Sementara Daemadi (2009, p. 27) merumuskan definisi nilai adalah sesuatu yang berharga baik menurut standar logika (benar-salah), estetika (bagus-baru), etika (adil atau layak-tidak adil), serta menjadi acuan dan atas sistem keyakinan diri maupun kehidupan. Jadi berdasarkan pendapat tersebut, pengertian nilai adalah memfokuskan pada sesuatu yang berharga ditinjau dari standar logika tertentu yang telah ditentukan sebelumnya. Standar logika sesuatu yang berharga itu dapat berupa benar-salah, bagus-buruk, adil-tidak adil, dan lain sebagainya. Nilai merupakan rujukan dan keyakinan dalam menentukan pilihan.

Sejalan dengan definisi itu, maka hakikat dan makna nilai berupa norma, etika, peraturan, adat kebiasaan, aturan agama dan rujukan lainnya yang memiliki harga dan rasakan berharga bagi seseorang dalam menjalani kehidupannya. Nilai bersifat abstrak, berada di balik fakta, memunculkan tindakan, dan terdapat dalam moral seseorang, muncul sebagai ujung proses psikologi dan berkembang ke arah yang lebih kompleks (Tim Pengembangan Ilmu Pendidikan FIP UPI, 2017).

Berdasarkan beberapa pengertian di atas, maka dapat ditarik kesimpulan bahwa nilai adalah rujukan dan keyakinan, dalam menentukan pilihan yang berharga, bermutu, menunjukkan kualitas, dan berguna bagi manusia. Nilai dapat dipahami sebagai sesuatu yang abstrak, ideal dan menyangkut persoalan keyakinan terhadap yang dikehendaki dan memberikan corak pada pola pikiran, perasaan dan perilaku. Dengan demikian untuk melacak sebuah nilai harus melalui pemaknaan terhadap kenyataan lain berupa tindakan, tingkah laku, pola pikir dan sikap seseorang atau sekelompok orang.

Karakter menurut Kamus Besar Bahasa Indonesia berarti sifat-sifat kejiwaan, akhlak, atau budi pekerti. Karakter dapat diartikan sebagai tabiat, yaitu perangai atau perbuatan yang selalu dilakukan atau kebiasaan. Suyanto (2009) mendefinisikan karakter sebagai cara berpikir dan berperilaku yang menjadi ciri khas tiap individu untuk hidup dan bekerja sama, baik dalam lingkup keluarga, masyarakat, bangsa, maupun Negara. Individu yang berkarakter baik adalah individu yang bias membuat keputusan dan siap mempertanggungjawabkan tiap akibat dari keputusan yang ia buat.

Syafaruddin (2012, p. 181) menyatakan bahwa pendidikan karakter merupakan proses penanaman karakter tertentu sekaligus menanamkan benih agar peserta didik mampu menumbuhkan karakter khasnya pada saat menjalankan kehidupannya, dengan kata lain peserta didik tidak hanya memahami pendidikan nilai sebagai bentuk pengetahuan, namun juga menjadikannya sebagai bagian dari hidup dan secara sadar hidup berdasarkan nilai tersebut.

Koesoma (2007, p. 124) pendidikan karakter merupakan bagian kinerja dari sebuah lembaga pendidikan yang di dalamnya terdapat berbagai macam keterlibatan individu dan tata aturan kelembagaan. Pendidikan karakter lebih tinggi dari pendidikan moral, karena bukan hanya mengajarkan mana yang benar dan salah tetapi juga menanamkan kebiasaan tentang hal yang baik sehingga siswa didik menjadi paham tentang hal yang baik sehingga siswa didik menjadi paham tentang mana yang benar dan salah, mampu merasakan nilai yang baik dan mau melakukannya (Tim Pengembangan Ilmu Pendidikan FPI-UPI, 2007, p. 243).

Selain dari pendapat di atas, Megawati (Koesoema, 2012, p. 5) mendefinisikan pendidikan karakter adalah sebuah usaha untuk mendidik anak-anak agar dapat mengambil keputusan dengan bijak dan mempraktikkannya dalam kehidupan sehari-hari, sehingga mereka dapat memberikan kontribusi yang positif kepada lingkungannya. Dari pendapat tersebut dapat disimpulkan bahwa pendidikan karakter adalah suatu usaha positif yang dilakukan seseorang untuk mendidik anak-anak. Hal demikian dimaksud agar mereka mampu berlatih mandiri dalam mengambil keputusan sehingga dapat mengaplikasikannya dalam kehidupan nyata sehari-hari.

Definisi lain dikemukakan oleh Muslich (2011, p. 29) pendidikan karakter adalah pendidikan budi pekerti plus, yaitu yang melibatkan aspek teori pengetahuan (cognitive), perasaan (feeling), dan tindakan (action). Menurut Thomas (Muslich, 2011, p. 29) tanpa ketiga aspek ini maka pendidikan karakter tidak akan efektif, dan pelaksanaannya pun harus dilakukan secara sistematis dan berkelanjutan. Dengan pendidikan karakter, seorang anak akan menjadi cerdas emosinya. Kecerdasan emosi adalah bekal terpenting dalam mempersiapkan anak menyongsong masa depan. Dengan 
kecerdasan emosi seseorang akan dapat berhasil dalam menghadapi segala tantangan untuk berhasil secara akademis.

Individu yang berkarakter baik atau unggul adalah seseorang yang berusaha melakukan hal-hal terbaik terhadap Tuhan Yang Maha Esa, dirinya, sesama, lingkungan, bangsa dan Negara. Pada dasarnya seorang siswa telah mengerti tentang kualitas karakter yang baik seperti kejujuran, ketaatan, tanggung jawab, dan lain sebagainya. Tetapi, hal tersebut tidak meresap di dalam hati sehingga siswa tidak mampu merasakan, memiliki keinginan, apalagi melakukan kualitas karakter tersebut dalam kehidupannya sehari-hari.

Tidak heran jika kita masih menjumpai siswa antar sekolah yang terlibat tawuran, siswa yang terjerumus dalam pemakaian narkoba, siswa yang bolos sekolah, siswa yang terlibat dalam pergaulan bebas, siswa yang mengucapkan kata-kata kasar kepada guru bahkan berani menganiaya gurunya sendiri. Oleh karena itu, pendidikan karakter tidak cukup hanya menyentuh akal pikiran tapi juga hati setiap peserta didik agar mereka mampu menghayati dengan benar dan pada akhirnya mengambil keputusan untuk melakukan serta memiliki karakter yang baik dalam hidupnya.

Menurut Koesoema (2010, p. 10) dalam artikelnya Pendidikan Krakter Itergral, pendidikan karakter jika ingin efektif dan utuh maka harus menyertakan tiga basis desain dalam pemogramannya. Pertama, desain pendidikan pendidikan karakter berbasis kelas. Desain ini berbasis pada relasi guru sebagai pendidik dan siswa sebagai pembelajar di dalam kelas. Konteks pendidikan karakter adalah proses rasional komunitas kelas dalam konteks pembelajaran. Relasi guru-pembelajaran bukan monolog, melainkan dialog dengan banyak arah sebab komunitas kelas terdiri dari guru dan siswa yang sama-sama berinteraksi dengan materi. Memberikan pemahaman dan pengertian akan keutamaan yang benar terjadi dalam konteks pengajaran ini, termasuk di dalamnya pula adalah ranah non instruksional, seperti manajemen kelas, konsensus kelas, dan lain-lain, yang membantu terciptanya suasana belajar yang nyaman.

Kedua, desain pendidikan karakter berbasis kultur sekolah. Desain ini mencoba membangun kultur sekolah yang mampu membentuk karakter anak didik dengan bantuan pranata sosial sekolah agar nilai tertentu terbentuk dan terbatinkan dalam diri siswa. Untuk menanamkan nilai kejujuran tidak cukup hanya dengan memberikan pesan-pesan moral kepada anak didik. Pesan moral ini mesti diperkuat dengan penciptaan kultur kejujuran melalui pembuatan tata peraturan sekolah tegas dan konsisten terhadap setiap perilaku ketidakjujuran.

Ketiga, desain pendidikan karakter berbasis komunitas. Dalam mendidik, komunitas sekolah tidak berjuang sendirian. Masyarakat di luar lembaga pendidikan, seperti keluarga, masyarakat umum, dan Negara juga memiliki tanggung jawab moral untuk mengintegrasikan pembentukan karakter dalam konteks kehidupan mereka.

Demi tercapainya pendidikan karakter yang berhasil di sekolah, tidaklah logis jika tuntutan itu hanya dialamatkan pada peserta didik. Tanggung jawab yang seharusnya lebih besar lagi justru terletak di pundak kita, para guru. Karena bagaimanapun setiap peserta didik atau siswa yang kita bina akan melihat contoh nyata pelaksanaan karakter yang kita ajarkan tidak lain dari perilaku maupun perkataan kita sehari-hari. Oleh sebab itu, guru harus menjadi teladan atau pelaku pertama dari karakter yang diajarkan kepada setiap anak didiknya. Menurut Koesoema (2007, p. 126) ada empat ciri dasar dalam penelitian karakter.

Pertama, keteraturan interior dimana setiap tindakan diukur berdasar hierarki nilai. Nilai menjadi pedoman normative setiap tindakan. Kedua, koherensi yang member keberanian, membuat seseorang teguh pada prinsip, tidak mudah terombang-ambing pada situasi baru atau takut risiko. Koherensi merupakan dasar yang membangun rasa percaya satu sama lain. Tidak adanya koherensi meruntuhkan kredibilitas seseorang. Ketiga, otonomi, dalam otonomi seseorang menginternalisasikan aturan dari luar sampai menjadi nilai-nilai bagi pribadi. Ini dapat dilihat melalui penilaian atas keputusan pribadi tanpa terpengaruh atau desakan pihak lain. Keempat, keteguhan dan kesetiaan, keteguhan merupakan 
daya tahan seseorang guna menginginkan apa yang dipandang baik. Dan kesetiaan merupakan dasar bagi penghormatan atas komitmen yang dipilih.

Ada 18 nilai pendidikan karakter yang telah dibuat dan dirancang oleh Depdiknas, antara lain: religius, jujur, toleransi, disiplin, kreatif, kerja keras, mandiri, demokratis, rasa ingin tahu, semangat kebangsaan, cinta tanah air, menghargai prestasi, komunikatif, cinta damai, gemar membaca, peduli lingkungan, peduli sosial, dan bertanggung jawab. Dari 18 nilai pendidikan karakter bangsa tersebut, diharapkan seluruh tingkat pendidikan di Indonesia mampu menerapkan nilai pendidikan karakter tersebut dalam proses pendidikannya (Depdiknas, 2011).

\section{Pembelajaran Sastra di SMA}

Pembelajaran sastra Indonesia, secara umum memiliki tujuan; (1) siswa mampu menikmati dan memanfaatkan karya sastra untuk mengembangkan kepribadian, memperluas wawasan kehidupan serta meningkatkan pengetahuan dan kemampuan berbahas; (2) siswa menghargai dan membanggakan sastra Indonesia sebagai khazanah budaya dan intelektual manusia Indonesia (Depdiknas, 2004, p. 2). Secara khusus pembelajaran sastra bertujuan agar siswa mampu mengapresiasi melalui kegiatan mendengarkan, menonton, membaca dan melisankan hasil sastra berupa puisi, cerita pendek, novel, drama, memahami dan menggunakan pengertian teknis kesusastraan dan sejarah sastra untuk menjelaskan, meresensi, menilai dan menganalisis hasil sastra, memerankan drama, menulis karya cipta sastra berupa puisi, cerita pendek, novel dan drama (Depdiknas, 2004, p. 4).

Selain memiliki tujuan dalam pembelajaran sastra Indonesia di SMA, Rahmanto (2000, p. 16-25) berpendapat bahwa pembelajaran sastra dapat membantu pendidikan secara utuh apabila cakupannya meliputi empat manfaat yaitu membantu keterampilan berbahasa, meningkatkan pengetahuan budaya, mengembangkan cipta rasa, serta menunjang pembentuka watak.

\section{METODE PENELITIAN}

Penelitian ini adalah penelitian kualitatif deskriptif. Sumber data penelitian ialah novel Cinta di Ujung Sajadah karya Asma Nadia. Jenis data berupa teks dengan wujud kata-kata, frase, kalimat, dan atau ungkapan yang relevan dengan tujuan penelitian. Data dikumpulkan dengan menggunakan teknik membaca intensif dan sistem pengodean. Membaca intensif adalah proses pembacaan secara cermat, berulang-ulang, dan mendalam untuk menemukan pemahaman maksimal terhadap bacaan dalam proses mengumpulkan data-data. Teknik pengodean adalah proses penandaan terhadap setiap data yang dianggap relevan dengan penelitian.

Data diolah dengan menggunakan teknik seleksi dan organisasi. Teknik seleksi adalah proses memilih dan memilah data-data yang benar-benar dianggap relevan dengan setiap fokus penelitian. Teknik organisasi adalah proses pengelompokan data berdasarkan fokus penelitian. Selanjutnya, data yang dikumpulkan dianalisis dengan menggunakan teknik interpretatif. Teknik interpretatif adalah proses pemaknaan, penafsiran, dan pendeskripsian terhadap data-data.

\section{HASIL DAN PEMBAHASAN}

Nilai pendidikan karakter bangsa yang berjumlah 18 menurut Depdiknas yaitu mencakup nilai religius, jujur, toleransi, disiplin, kreatif, kerja keras, mandiri, demokratis, rasa ingin tahu, semangat kebangsaan, cinta tanah air, menghargai prestasi, komunikatif, cinta damai, gemar membaca, peduli lingkungan, peduli sosial, tanggung jawab, dan cinta tanah air.

\section{Nilai Religius}

Salah satu cakupan nilai pendidikan karakter menurut Depdiknas adalah nilai religius. Nilai religius merupakan konsep mengenai penghargaan tinggi yang diberikan oleh warga masyarakat kepada beberapa masalah pokok dalam kehidupan keagamaan yang bersifat suci sehingga dijadikan 
pedoman bagi tingkah laku keagamaan warga masyarakat yang bersangkutan. Adapun nilai-nilai religius yang terdapat dalam novel Cinta diUjung Sajadah karya Asma Nadia bisa dilihat dalam kutipan-kutipan berikut:

Data 001

"Wajar surga ditaruh di kaki Ummi, ya?" Aisyah tersenyum lagi. Pipinya yang tembem dalam haru bergerak-gerak",”. (D1H36)

Konteks yang terjadi pada data tersebut adalah pada saat Cinta berdiskusi dengan sahabatsahabatnya mengenai keunggulan-keunggulan yang dimiliki ibu mereka. Data diatas mengandung nilai religius karena mengingatkan bahwa setiap manusia harus patuh kepada orang tuanya terutama ibu sebab menurut ajaran agama, surga itu berada di bawah telapak kaki ibu. Alasan kenapa sampai surga yang begitu indah dan tak ada bandingannya di dunia itu ada di kaki ibu, adalah karena mereka kita ada.Bukan bim salabim, mereka harus bersusah payah membawa beban berat dalam waktu yang sangat lama.

Mengandung tidaklah semudah yang kita kira.Hamil itu sangat menyusahkan dan ibu melakukannya dengan wajah bahagia.Sejujurnya, ibu merasakan beban yang luar biasa saat mengandung.Bahkan ingin sesekali mereka menaruh jabang bayi ini dulu hanya untuk sekedar meluruskan punggungnya.Tapi tidak, ibu tidak demikian.Meskipun terlihat payah, tapi tanyakanlah kepada ayah betapa ibu saat itu sangat sumringah wajahnya.

\section{Nilai Kejujuran}

Nilai kejujuran adalah salah satu sikap yang dimana perbuatannya, ucapannya yag dikeluarkan dari hati, sesuai dengan fakta. Nilai kejujuran harus diteladani setiap orang seperti sifat yang diteladani Rasulullah SAW adalah merupakan contoh terbaik dan seorang yang memiliki pribadi utama dalam hal kejujuran. Pada zaman sekarang sulit ditemukan orang yang jujur, hal ini dikarenakan orang beranggap jika kita jujur orang akan menjauh dan akan berdampak buruk pada diri sendiri. Ketidakpercayaan diri sendiri dan ketakutan jika kita bicara benar akan dikucilkan yang membuat diri kita berbohong.

Apalagi sebagai seorang peserta didik yang mematuhi aturan, bersikap jujur adalah wajib. Setelah memahami makna jujur, maka peserta didik dapat menyikapi sebuah permasalahan yang dihadapi. Selain itu, dengan bersikap jujur, mampu menjadikan peserta didik sebagai seorang yang dapat dipercaya pada kemudian hari. Sehingga dalam novel ini akan ditampilkan kutipan-kutipan yang mengandung nilai kejujuran yakni sebagai berikut:

Data 002

"Bahkan ada yang terang-terangan membenci, Aku benci dia Cinta, benci sekali. Raut wajah Cinta seperti bertanya, kenapa? Tapi Mirna teman sekelasnya tak pernah bercerita lebih jauh. Hanya bibirnya yang terkatuk rapat dan sorot mata yang tiap hari kian serat kebencian”. (D1H36)

Konteks pada data tersebut adalah ketika Cinta dan teman-temannya sedang membicarakan ibu mereka masing-masing, namun salah satu teman Cinta yang bernama Mirna tiba-tiba mengeluarkan perkataan yang sangat mengagetkan Cinta dan teman-temannya yang lain, ketika itu Mirna mengatakan bahwa ia sangat membenci sosok yang dipanggilnya ibu itu, dari sorotan matanya sangat jelas menunjukkan kebencian yang sangat mendalam. 


\section{Nilai Toleransi}

Toleransi merupakan sikap saling menghargai satu sama lain. Toleransi baik diterapkan pada peserta didik, agar peserta didik mampu menghargai satu sama lain dan mengetahui bahwa toleransi sangat penting diterapkan dalam kehidupan sehari-hari baik dalam lingkup keluarga bahkan masyarakat. Toleransi dalam lingkup keluarga ataupun masyarkat pada dasarnya mengajarkan kita untuk saling menghargai perbedaan yang ada, baik itu pendapat, kepercayaan, kelakuan, kebiasaan dan lain sebagainya.

\section{Data 003}

"Kenapa? Mungkin karena Ummi suka memiliki anak banyak. Mungkin karena Ummi berprinsip banyak anak banyak rezeki. Mungkin karena alasan prinsip, Ummi tidak mau ikut KB dan semacamnya. Mungkin juga karena alasan lain, yang Cinta tidak tahu”. (D1H81)

Konteks yang terjadi pada data di atas terjadi ketika Aisyah dan Cinta berbincang-bincang mengenai Ibu Aisyah yang sering dipanggil Ummi itu. Pada data di atas terdapat nilai toleransi di dalamnya. Dari hasil analisis penulis nilai toleransi dibuktikan dari sikap Cinta yang secara jelas menggambarkan bahwa tidak ada masalah dalam kehamilan baru Ummi yang akan menambah anak lagi. Ia beranggapan bahwa mungkin Ummi menyukai memiliki banyak anak, atau mungkin Ummi memiliki alasan lain yang Cinta tidak ketahui. Namun, tidak menuntut kemungkinan bahwa Ummi tidak akan menyayangi anaknya yang lain, tetapi Ummi membuktikan bahwa ia tetap akan memberikan perhatian yang lebih kepada anaknya yang lain.

\section{Peduli Sosial}

Peduli merupakan kemauan untuk berbuat baik berupa perhatian, maupun waktu, bantuan pikiran, waktu, tenaga, dan sebagainya. Bila dikaitkan dengan peserta didik tentu saja hal ini sangat berkaitan satu sama lain. Dengan bersikap peduli, peserta didik mampu memotivasi diri untuk lebih mengerti keadaan sekitar. Peduli juga tidak menghitung-hitung keuntungan atau balasan apapun yang akan diterima selanjutnya.

Data 004

"Untunglah Makky berkali-kali menyelamatkan Cinta, dengan menawarkan gadis yang kebingungan itu tumpangan. "Naik Cinta, biar saya antar"”. (D1H96)

Data di atas terjadi ketika Cinta yang terlambat ke sekolah dan hanya berjalan kaki, tiba-tiba Makky datang dan menawarkan tumpangan kepada Cinta. Cinta yang kala itu tergesa-gesa langsung saja menerima ajakan Makky walaupun sebenarnya ia takut akan diketahui oleh saudari tirinya yang sudah menyimpan rasa kepada Makky. Namun, Cinta menghargai kepedulian Makky kepadanya. Kepedulian itu ditunjukkan dengan sikap Makky yang secara dengan senang hati menawarkan Cinta tumpangan tanpa ia minta. Sehingga dari hasil analisis penulis maka data di atas mengandung nilai peduli sosial.

Peduli sosial sangat penting dimiliki oleh seorang peserta didik, agar mereka dapat mengetahui apa yang dirasakan orang-orang yang ada di sekitarnya, dan juga peserta didik mampu bersosialisasi dengan baik. Hal ini terkadang di hiraukan oleh beberapa tenaga pendidik, nyatanya hal ini lah yang seharusnya ditanamkan dalam diri peserta didik. 
Data 005

"Harusnya kita tengok, ujian sudah dekat. Ada yang tahu ngga alamatnya?" cinta mengedarkan pandangan ke sekelilingnya. Semua menggeleng. Tidak ada yang tahu alamat Mirna. Akhirnya Neta yang biasa jadi seksi sibuk, segera mengambil inisiatif. “ Kita tanya aja alamatnya di tata usah. Terus siang ini pulang sekolah kita jenguk"”. (D2H107-108)

Data di atas terjadi ketika Cinta dan teman-temannya sedang berkumpul dan membicarakan ujian yang sebentar lagi akan dilaksanakan. Namun, salah satu dari teman sekelas Cinta yang bernama Mirna telah beberapa hari tidak masuk sekolah. Akhirnya mereka berencana untuk menjenguk Mirna yang kabarnya tengah sakit.

\section{Rasa Ingin Tahu}

Rasa ingin tahu sering dialami oleh peserta didik ketika mereka mempunyai atau mengalami suatu pengalaman dan pembelajaran baru, yang sebelumnya belum pernah mereka dapatkan. Hal ini baik dalam pembelajaran, karena mampu meningkatkan pengetahuan siswa. Sama halnya dengan beberapa kutipan dibawah ini yang mengandung nilai rasa keingintahuan tentang sesuatu hal.

Data 006

"Maaf kalau ini lancang," cetus saya lagi, " tapi apakah karena Cinta tidak bisa... eh maksud saya, belum memiliki momongan sendiri?" Pertanyaan itu mungkin sensitif bagi beberapa orang. Mungkin juga bagi Cinta. Perempuan berkulit putih itu terdiam beberapa saat setelah mendengarnya. Tetapi senyumnya segera terkembang.".(D1H7)

Konteks yang terjadi pada data diatas ketika seorang wartawan yang bertanya kepada Cinta tentang kisahnya dahulu. Saat itu Cinta hanya terdiam mendengar pertanyaan sang wartawan karena menurutnya sangat sensitif hal ini diceritakan karena menyangkut nama keluarganya sendiri. Namun saat itu sang wartawan tetap mendesak Cinta agar bercerita tentang hal itu, dan pada akhirnya mulailah Cinta bercerita tentang kisah hidupnya mulai dari kecil hingga saat ini.

\section{Nilai Komunikatif}

Komunikatif adalah suatu cara agar membentuk suatu hubungan komunikasi antar peserta didik satu dan yang lainnya. Hal ini dapat dilatih dengan memberikan tugas kelompok, berdiskusi, maupun dengan hal lainnya.

Data 007

"Sudah dekat. Kata ibu warung, sekitar sepuluh meter lagi". Nete menunjuk ke satu arah". (D1H110)

Data di atas terjadi ketika Neta menunjuk pada satu arah, yakni kearah rumah Mirna.Mereka yang sedari tadi mencari rumah Mirna akhirnya menemukannya juga.Hal ini ditandai dengan petunjuk yang diberiak salah satu penjaga warung yang mereka tempati untuk beristirahat dan mengumpulkan tenaga.

\section{Bertanggung Jawab}

Tanggung jawab merupakan satu hal yang wajib dimiliki dan dipelajari oleh seluruh peserta didik. Karena dengan menjadi orang yang bertanggungjawab peserta didik mampu menjadi orang yang 
dipercaya untuk menyelesaikan suatu hal yang dipercaya kepada mereka. Hal ini dapat berupa pekerjaan rumah maupun tugas-tugas lainnya.

Data 008

"Pasrah, Mbok Nah menyerahkan selembar amplop usang ke tangan Cinta. Beberapa detik setelah amplop putih lusuh itu berpindah tangan, Mbok Nah merasa dirinya terbebas dari beban berat. Surat-surat itu sudah kusampaikan, Yuningsih... seperti janji Mbok!”. (D1H158)

Konteks yang terjadi pada data di atas ketika Cinta dan Mbok Nah berbicara bersama mengenai rahasia yang selama ini dirahasikan oleh orang-orang yang ada di rumahnya temasuk Mbok Nah. Hal ini dikarenakan ibu kandung Cinta yang bernama Ayuningsih ini melarang Mbok Nak mengatakan pada Cinta sebelum berusia 17 tahun.

Menurut Depdiknas terdapat 18 nilai pendidikan karakter bangsa yang harus dimiliki oleh peserta didik sebagai calon penerus bangsa, yang mencakup nilai religius, jujur, toleransi, disiplin, kerja keras, kreatif, demokratis, rasa ingin tahu, semangat kebangsaan, komunikatif, gemar membaca, pedul lingkungan, peduli sosial, mandiri, tanggung jawab, cinta tanah air, menghargai prestasi, cinta damai. Namun, dari 18 nilai tersebut hanya ada beberapa nilai yang terkandung dalam novel Cinta di Ujung Sajadah, yang kemudian dikategorikan ke dalamempat kriteria yang pertama, nilai pendidikan karakter antara manusia dengan Tuhan yang mencakup nilai pendidikan karakter bangsa religius.

Kedua, nilai pendidikan karakter antara manusia dengan dirinya sendiri yang mencakup nilai pendidikan karakter bertanggungjawab.Ketiga, nilai pendidikan karakter antara manusia dengan masyarakat yang mencakup nilai pendidikan karakter jujur, rasa ingin tahu, peduli sosial, toleransi dan komunikatif.

Novel Cinta di Ujung Sajadah dapat digunakan sebagai bahan pembelajaran sastra, karena di dalamnya terdapat kalimat-kalimat yang memunculkan situasi baru yang menarik bagi peserta didik, merupakan bacaan yang memiliki kisah romansa berbalut dakwah, sehingga dapat digunakan sebagai bacaan wajib bagi peserta didik.

\section{KESIMPULAN DAN SARAN}

Novel Cinta di Ujung Sajadah karya Asma Nadia ini, dapat dijadikan sebagai materi pembelajaran sastra pada satuan pendidikan Sekolah Menengah Atas atau SMA. Hal tersebut dikarenakan novel Cinta di Ujung Sajadah karya Asma Nadia memiliki bahasa yang estetis, yaitu mudah dipahami oleh siswa. Selain itu, banyak fenomena sosial yang menyampaikan pesan dan kesan mendidik secara objektif sehingga bagi siswa yang membacanya seakan ikut berpetualang dalam alur cerita. Hasil penelitian ini dapat menjadi rujukan terhadap berbagai pihak.

Pertama, Novel Cinta di Ujung Sajadah karya Asma Nadia dapat dijadikan sebagai bahan bacaan sebagai penguatan literasi membaca di sekolah atau kegiatan membaca sastra dapat dijadikan sebagai kegiatan ekstrakurikuler. Kedua, memberi kesempatan dan ruang secara kreatif kepada guru, khususnya guru mata pelajaran bahasa Indonesia. Ketiga, merangsang dan meningkatkan minat baca siswa. Keempat, dapat dijadikan sebagai bahan bacaan untuk masyarakat umum di setiap usia. 


\section{DAFTAR PUSTAKA}

Darmodiharjo, Darji. (2010). Pokok-pokok Filsafat Hukum. Jakarta: Gramedia Umum.

Desi, Amalia Saputri, (2012). Nilai Pendidikan Karakter dalam Novel Sepatu Dahlan Karya Kherisna Pabichara. Skripsi. Purwokerto: Universitas Purwokerto.

Dipdiknas. (2007). Buku Praktis Bahasa Indonesia. Jakarta: PusatBahasa.

Koesoema, Doni. (2007). Pendidikan Karakter. Jakarta: PT. Grasindo.

Lubis, Mawardi. (2008). Evaluasi Nilai Pendidikan. Yogyakarta: Pustaka Pelajar.

Muslich, Masnur. (2011). Pendidikan Karakter. Bandung: Alfabeta.

Nadia, Asma. (2012). Cinta di Ujung Sajadah. Jakarta: Republika Penerbit.

Rahmanto, E. (2000). Metode Pengajaran Sastra. Yogyakarta: Kanisius.

Sulaiman, Ahmad. (2015). Nilai-nilai Pendidikan Krakter dalam Novel Cinta di Ujung Sajadah Karya Asma Nadia serta Relevansinya dengan Materi Pendidikan Agama Islam di SMA. Skripsi. Purwokerto: Institut Agama Islam Negeri Purwokerto.

Suyanto. (2009). Urgensi Pendidikan Karakter. Artikel. [Online]. Diperoleh dari http://www.mandikdasmen.depdiknas.go.id/web/pages/urgensi.html. Diakses pada 18 Juni 2018.

Syafaruddin. (2012). Pendidikan dan Pemberdayaan Masyarakat. Medan: Perdana Publishing.

Tim Pengembangan Ilmu Pendidikan FIP-UPI. (2007). Ilmu dan Aplikasi Pendidikan. Jakarta: PT. Grasindo.

Widiyastuti, Endang. 2016. Analisis Psikologi Tokoh Utama Novel Meniti Langkah Karya Sutri Yaningsih Manik dan Pembelajarannya di Kelas XI SMA. Skripsi. Purworejo: Universitas Muhammadiyah Purworejo. 